Instructions for authors, subscriptions and further details:

\title{
http://rimcis.hipatiapress.com
}

\section{Determination of Women Voting Behavior: A Machine Learning Approach in the Turkish Political Arena}

Havva Çaha ${ }^{1}$, Nizamettin Bayyurt ${ }^{2}$

1) Mardin Artuklu University, Mardin, Turkey

2) Istanbul Technical University, Istanbul, Turkey

Date of publication: article first published online September 8, 2020; Issue published November 30, 2020

Edition period: November 2020 - March 2021

To cite this article: Çaha, H., \& Bayyurt, N. (2020). Determination of Women Voting Behavior. A Machine Learning Approach in the Turkish Political Arena. International and Multidisciplinary Journal of Social Sciences, 9(3), 260-288 . doi :10.17583/rimcis.2020.5027

To link this article: http://doi.org/10.17583/rimcis.2020.5027

\section{PLEASE SCROLL DOWN FOR ARTICLE}

The terms and conditions of use are related to the Open Journal System and to Creative Commons Attribution License(CC-BY). 


\section{Determination of Women Voting Behavior: A Machine Learning Approach in the Turkish Political Arena}

Havva Çaha

Mardin Artuklu University
Nizamettin Bayyurt

Istanbul Technical University

\section{Abstract}

Justice and Development Party (AKP) has been the ruling and biggest party in Turkey (AKP) since it has been established in 2002 and Republican People's Party (CHP) has been the main opposition party (CHP) since then. These two parties receive about $75 \%$ of all the votes. In Turkey half of the voters are females. In this study, the important attributes of women in party selection decisions are analyzed. To our knowledge, there is no such a study focusing on women's party preferences in Turkey. Additionally, this is one of the very few studies in Turkey concerning voters' party preferences. Therefore, this study aims to fill this gap in the literature. Center-periphery and social mobility theories are the two main theories explaining Turkish political life. The analyzed ideological, cultural, religious, social, economic and demographic characteristics of women supporters are selected according to these theories. Machine-learning techniques are employed as predictive tools. Results show that ideological attitudes like being leftist-rightist and religious values like headscarf, fasting in Ramadan, and praying are the most important effective attributes on party selection of women. However, socio-economic, cultural, educational and demographic atributes are not effective on party selection of women in Turkey.

Keywords: women voters, machine learning, AKP, CHP, Turkey 


\section{Determinar el Comportamiento Electoral de las Mujeres. Una Aproximación del Aprendizaje Automático a la Arena Política Turca}

Havva Çaha

Mardin Artuklu University
Nizamettin Bayyurt

Istanbul Technical University

\section{Resumen}

El partido de la Justicia y el Desarrollo (AKP) ha sido el mayor y predominante en Turquía desde que se estableció en 2002, y el partido de la República del Pueblo (CHP) ha sido el principal partido opositor desde entonces. Ambos partidos reciben alrededor del $75 \%$ de todos los votos. En Turquía la mitad de los votantes son mujeres. En este estudio se analizan los atributos más importantes en la decisión de las mujeresde escoger partido. No hay un estudio centrado en las preferencias políticas de las mujeres en Turquía. Además, este es uno de los pocos estudios sobre las preferencias de los votantes en Turquía. De ahí que este estudio pretenda llenar este vacío en la literatura.Dos de las principales teorías para explicar la vida política turca son la del centro-periferia y la de la movilidad social. En base a estas teorías se han escogido las características de los apoyos femeninos, tales como las ideológicas, las culturales, las religiosas, las sociales, las económicas y la demográficas. Se han usado técnicas de aprendizaje automático como herramientas predictivas. Los resultados muestran que las actitudes ideológicas como ser de izquierdas o ser de derechas y los valores religiosos como llevar velo, ayunar en Ramadán y rezar son los atributos más importantes y efectivos en la selección de partidos por parte de las mujeres. Sin embargo, los atributos socio-económicos, culturales, educativos y demográficos no son efectivos en la elección de partidos de las mujeres en Turquía.

Palabras clave:mujeres votantes, aprendizaje automático, AKP, CHP, Turquía 
urkey is a democratic government that has exerted westernization efforts since its foundation. It was governed with a single party system until the 1950s. Along with transition to a multi-party system, the governments come to power through elections. Until the 1970s, only the parties that were at the right-left axle had been established in Turkey. The religionist and conservative sections that form a big part of the community mostly had voted for the right-sided parties until the 1970s. Although the Islamist parties that had been established in Turkey since 1972 were closed on the grounds of that they had been threatening the secular regime, a new follow-up party was established replacing each party that was closed.

Justice and Development Party (AKP), established in 2001 by people coming from Islamist tradition and people coming from democrat party, has been alone in power since 2002. AKP, which defines itself as conservative democrat, is much more successful in terms of receiving the majority of votes over the region. Although the criticism concerning that Turkey has been increasingly conservative are made by some sections of the public, it is a truth that the strategies developed by the opposition parties devoted to gaining power have not given the desired results on the basis of the voters. A big part of the discussions that have been going on between Kemalists (Kemalism is the founding ideology of the Republic of Turkey.It was defined by sweeping political, social, cultural and religious reforms designed to separate the new Turkish state from its Ottoman predecessor and embrace a modernized lifestyle, including the establishment of democracy, secularism, and state support of the sciences and free education, many of which were first introduced to Turkey during Atatürk's presidency in his reforms (Wikipedia, n.d.) and Islamists in the recent years were related to the women topic. This study aims to estimate party preferences of the women voters by reviewing their religious, ideological, and socio-cultural characteristics. Therefore, the research question of the study is formulated as "what are the critical determinants of Turkish women's voting preferences in party selection?". Machine learning algorithms are employed as predictive tools. This is one of the very few studies in Turkey concerning voters' party preferences. To our knowledge, there is no such a study focusing especially on women's party preferences in Turkey. 


\section{Literature Review}

Although there has been a multi-party system in Turkey since the 1950s, empiric studies concerning determination of voter behaviors and preferences are very few. Among those, the studies of Ozbudun and Tachau (1975), Ozbudun (1976), Kalaycioğlu (1994), Esmer (1995), and Keyman and Öniş (2003) draw attention. Within the scope of centre-periphery approach, the socio-cultural variables are generally used to explain behaviors of the voters in Turkey (Frey, 1975). According to Shils, who is the founder of centreperiphery theory, there is a group of elite who may be defined as centre and who are at the power or may affect the government within every community. Although these groups that are defined as centre are outnumbered, they form policies devoted to infusing these values into the community as they own the decision-making mechanisms or they have power to affect decision-makers. These elite who are at the centre see themselves superior to other groups that form the community (Shils, 1975).

$\mathrm{Ab}$ initio, Turkish political life has been established based on the centre and periphery contrast. While the statist elite consisting of prowesternization soldiers and bureaucrats form the centre, the people and groups who have traditionalist-Islamist understanding take place at the periphery (Ergüder, 1980). Republican People's Party (CHP), that was established by Atatürk in 1923 under the name of the People's Party and then took the name of Republican People's Party in 1935, represented the centre between the years of 1923 and 1946. These years were assessed as "the single-party term" during which CHP was able to keep the periphery under control. In the upcoming years, CHP added within its body the people from the country who adopted its values (Mardin, 1995). During these years, the statist elite assessed a big part of the community as the illiterates who showed resistance to innovations and who needed to be developed (Heper,1985). Within this process, it was seen that communal groups taking part in the centre and periphery were increasingly becoming different and sometimes entered into the conflicts (Lewis, 2008). Inclusion of voters into the political system in Turkey has generated the multiple-party term. The Democratic Party (DP) came to power by taking 55\% of the votes in 1950 with the discourses such as that it would be the party of villagers, it would decrease effects of the bureaucracy, it would liberate religious practices, and 
freedoms would be increased (Mardin, 1973). The dissatisfaction of the voters, mainly villagers and country tradesmen who did not find any representation party in the single-party term, had harsh feelings against CHP and that was enough for them to support DP (Tachau, 1991). Therefore, DP that represented the traditional values in the upcoming years was considered as "democratic periphery" and CHP that had been defender of the reforms was considered as "bureaucratic centre" (Sakallığlu, 1996).

Right-rooted parties are defined as close periphery and far periphery depending on the distance from the Kemalist regime. The parties that do not reject the Kemalist values even if they do criticize these values may be taken into hand as close periphery. The close periphery parties at the centre right that have learned from the DP example of being closed with the military coup in 1960 established good relations with the bureaucracy (Sakallioglu, 1996). Islamist groups have voted for centre right parties until the 1970s, and after 1972 they established their own parties (Narl1, 1999). The first established Islamist party was The National Salvation Party (MSP). MSP, RP (Welfare Party) and FP (Virtue Party) that came from Islamist tradition were assessed as far periphery. These parties were closed on the grounds that they were propagating sharia law (Gönenç, 2006).

CHP, the state party, has used a political discourse close to the periphery since the 1960s with the aim of taking the power of the democratic system (Kalaycığlu, 1994). CHP states that it is the party of oppressed ones, employees, and labor with concept of the intermediate left (Tekeli, 1993). Along with discourse of the intermediate left, 33\% of the votes in 1973 and $42 \%$ of the votes in 1977 brought CHP to power. The point that draws the attention here is that CHP was able to come to power by using values and discourses of the periphery at both of the elections (Tachau, 1991). Even though it was said in the 1970s that Islamist parties made discourses on notables, small craftsmen, and craftspeople and left parties focused on the working class and class differences were effective on the party preference, it was seen that piety, regional ties and blood ties are more important in terms of party preference in Turkey (Kalaycioğlu, 1994). Since the 1980s, Kemalism has started to weaken and centre right and centre left parties have started to lose votes from the poor community, and as a result Islamism has started to rise (Narlı, 1999; Sakallığlu, 1996). 
Social mobility model is also frequently used to explain behaviors of the voters in Turkey. According to the social mobility theory, socio-economical level also plays an important role in the party preference. As high level socio-economical groups gain much more economical and financial earnings on the ground of the available political system, they support the parties that defend the available system (Ozbudun, 1976). In developing countries like Turkey, the government is the most determinant factor that allocates resources. While the people and theories close to official ideology richen with the transfers of the government, opposing groups are getting poor (Kalaycioğlu, 1994). Turkey had a closed economical system up to the 1980s. It was hard to say that the people who were not close to official ideology had big successes in their business life. In the 1980s, with the adaptation of export-orientation industrialization strategy, Turkey has started to open to foreign countries. Small and medium scaled enterprises in Anatolia with a religious identity adopted an exportation-based strategy in these years. With this approach a new bourgeois class, called as the Anatolian Tiger, started to be formed in Turkey. This situation has led to social mobility along with it. In Turkey, the business environments who did not want to lose their economical benefits they had gained as a result of their closeness to the official ideology, have supported the left parties having a statist economical understanding.

\section{A New Era: Power of Islamist Conservatives and Left Opposition}

The economic crisis that was experienced in 2001 has led to a new era in Turkey. After this crisis, the Motherland Party (ANAP) that was the biggest party of the centre right has not been able to enter the Grand National Assembly of Turkey in 2002. The Islamist Virtue Party (FP) was closed in 2002. After the closure of FP section of people with a more traditional view have joined the Felicity Party (SP) and the people who were known as more reformist established a new party called AKP. Center right parliament members, mainly belonging to ANAP, had a very big effect on the formation of AKP (Mert, 2007). AKP has been differentiating itself from its roots(Welfare Party, Felicity Party, and Virtue Party ) stating that it's a mass party with a conservative basis. It is seen that AKP voters' base is generally 
formed of religious, conservative, Islamist voters, and voters with a right tendency (Dalmış \& Aydın, 2008).

AKP gained $34.26 \%$ of the votes in the 2002 general parliament elections and $46.6 \%$ of the votes in $2007,49.95 \%$ in 2011 , and $49.3 \%$ of the votes in 2015 general elections. On the other hand, CHP took $19.4 \%$ of the votes in $2002,20.9 \%$ of the votes in $2007,25.94 \%$ in 2011 , and $25.4 \%$ of the votes in 2015 general elections. AKP has taken place in power in these elections. After the presidential election in 2007, there have been discussions concerning whether the Islamistic periphery has become the new centre. This situation has led to conflicts between the secular Kemalists (mainly formed by bureaucrats and soldiers) at the centre and conservatists at the periphery (Tuncel \& Gündoğmuş, 2012). Biggest part of of these discussions was devoted to the women topic (Çaha, 2010; Adakl1, 2009).

This study aims to determine the differences between AKP and CHP women voters that have been at the center of these discussions.

\section{The Differentiation Points between AKP and CHP Women Voters}

The studies conducted concerning voters in Turkey show that voting behavior is influenced by religiousness, beliefs and values rather than by mind, logic, and cause and effect relations (Erkan, 2000). Especially religious attitudes and discourses of the parties determine the vote ratios (Kalaycığlu, 1994). The differences between AKP and CHP women voters can be collected under three titles by means of center-periphery and social mobility theories. 1. Religious values, attitudes, and practices; 2. Education levels; 3. Participation to social and cultural activities and reading habits.

\section{Religious Values, Practices, and Attitudes}

In the 1980s, religious people and religious groups have been affecting political systems (Hammond, 1999). By the subversion of socialist regimes, religious and moral values have started to rise in these countries (Berger, 1999). In Turkey, religious values were put forward as a reflex against the communism after the military coup in the 1980s. Religion lessons were added to the curriculum as compulsory lessons. An increasing number of people in Turkey take religion as reference in their life opinions and daily 
life practices such as fasting in Ramadan, reading the Koran, performing salaah, and wearing a headscarf.

Approximately $60 \%$ of women in Turkey cover their head in the public areas. While some women cover their head traditionally, some part of them cover their head with conscious preferences. Although this is such a common practice, the main axle of the discussions that are done between AKP and CHP is about wearing of the headscarf (Ilyasoğlu, 1994). Since the first years of Republican Term, Kemalism has been encouraging women in terms of being in the public area. In the revolutions that were done concerning clothes, the disposition of the headscarf was considered as an indicator of modernization (Göle, 1997). Bare-headness was put forward as a modern women symbol and women were loaded protector mission of the revolution (Çağatay \& Soysal, 1990). Therefore secular Kemalist women are opposed to headscarfs on the grounds that it is a political attitude against the Kemalist system (Cinar, 2008; Arat, 2010). The feminist women who have gained power since the 1980s are opposed to the headscarf on the grounds that it restricts freedom of women (Pak, 2006). Headscarf ban has directly and indirectly hardened the situation of women and provided continuance of paternalistic structures (Güveli, 2011).

AKP and CHP had completely opposite views related to the education right and right to work in public institutions of women with headscarf. While AKP produces a policy at the axle of "public and private area" discussions, CHP emphasized "secularism and democracy" discourses. According to CHP, headscarfs may be used in the private life. But if women want to take place in the public life, they are expected to remove their headscarf. Along with that according to the public surveys that were done, $76 \%$ of women are opposed to the headscarf ban and $72 \%$ of women want rescission of this ban (Çarkoglu \& Toprak, 2000). Until recent years, headscarfs had been forbidden in the public life. The headscarf ban was rescinded first in universities in 2007 and then in public offices in 2013.

To perform salaah is the primary religion practice. When we look into the prayer attitudes of women, a big part of women who vote for AKP stated that they do pray. More than half of women who vote for CHP pray as well. Another aspect drawing attention here is that there are women in CHP who perform salaah and wear headscarfs, on the other hand among AKP voters there are women who do not perform salaah and do not wear headscarfs. 
It is seen that fasting in Ramadan is carried out by most women independent of their party preferences. Numbers of women who stated that they are not fasting are a lot less among AKP voters. More than half of the women who vote for CHP fast regularly and the number of women who fast occasionally are significant. The fasting worship is done more commonly than performing salaah. While performing salaah is a worship that requires stricter adherence, such as every day of the week and five times a day, the fasting is a worship that is only done in the Ramadan month once a year. Reading the Koran is another common practice among women. Another discussion among AKP and CHP is about consumption of alcohol. CHP claims that AKP restricts personal freedoms by banning alcohol. Along with that, alcohol consumption has been increasing in Turkey. The alcohol consumption that was 505.4 million liters in 2003 had reached to 943.9 million liters in 2008 (Milliyet, 2009). Within the scope of the law that was legislated in Turkey June $11^{\text {th }}, 2013$, advertisements of alcohol drinks and promotion activities devoted to consumers were banned. This law also banned alcohol sales at specific places like dormitories, stadiums, sport halls and education institutions. The provision that the places selling alcohol will be at least $100 \mathrm{~m}$ away from education institutions and prayer houses was legalized (Resmi Gazete, 2013). CHP rejected and brought this law to the Constitutional Court. Consumption of alcohol is seen as an important factor that affects party preferences of women. Islam religion bans consumption of alcohol.

Optional abortion was liberated in the 1980s on the conditions meeting some definite aspects. According to the law, abortion that will be done without showing any reason is liberated in the first ten weeks of pregnancy and it will be liberated in the later periods if there is medical obligation. Along with this law, women are able to have an abortion in the state hospitals at low cost. In the upcoming years, numbers of women who had abortion have been increased. According to the report of the International Population Planning Federation that was published in 1994, Turkey is among the countries in Europe that has had the most abortions. While the abortion number was 33 thousand in 2002, this amount reached to 79 thousand in 2012 (Sabah, 2014). In Turkey, the discussions concerning abortion have started after the declaration of Prime Minister R. Tayyip Erdoğan stating that abortion is murder on 26 May 2012. After this 
declaration, the secular Kemalist women participated in protest demonstrations of various Civil Society Organizations, mainly the Turkish Medical Association. Against that, abortion up to 10 weeks is free in Turkey now. Along with that, Islamist women are opposed to abortion as a principle, they are also opposed that government adopts policies devoted to women's bodies (Aksoy, 2015). The Islam religion does not give permission for abortion. In this subject, Directorate of Religion Affairs states that abortion is a sin (Hürriyet, 2012).

Flirtation had been an issue that had been discussed in Turkey for the past 30 years. There was news media talk concerning that conservatist sections were opposed to flirting. Nowadays, it is seen that also conservatist section takes flirtation issue more tolerantly. According to Table 6, most of the women who stated that they vote for AKP had a positive attitude in terms of flirting. Most of the women who stated that they vote for CHP find flirting favourable.

A big part of women who either vote for AKP or vote for CHP reject cohabitation, which is the living together of a man and a woman without marriage. A big part of women who take cohabitation as negative has been perceiving this as a threat to the community and family structure.

\section{Education}

Although the importance of women's education has been emphasized since proclamation of the Republic, desired success has not been achieved. Not sending girls to schools form the basis of criticism of the Kemalists towards the Islamists. The approach of Islamists not allowing girls to go to school has started to change by the opening of religious high schools called imam hatip in the 1970s. The efforts of girls with headscarfs who were graduated from these schools for entering to universities since the 1980s formed the centre of the head-scarf discussions in the upcoming years. Additionally women with a university degree wearing headscarfs were banned from the public sector.

Prevention of women with headscarf from education and work labor leads to various problems. Education is the most important aspect of starting a career and entering social mobility in the modern communities. Depriving women with headscarfs from this right prevents them to reach higher income 
class. As the education level of women increase, their future expectations also change and this leads to an upward communal mobility (Ruspini \& Dale, 2002). The headscarf ban prevented women from the labor force. This leads to the wastage of the communal and financial resources. With the rescission of the headscarf ban, it is expected that religious people will much more participate in the education and business life.

When the relation between education levels and voting behaviors of Turkish voters were taken into account, it was seen that approximately $60 \%$ of the voters who voted for AKP in 2007 elections had a low education level, $30 \%$ of them had medium education level, and only $10 \%$ of them had high education level. In the same election, it was seen that CHP took more votes from highly educated voters (Dalmış \& Aydın, 2008).

\section{Participation in Social and Cultural Activities and Reading Habits}

Within the scope of this research, it was analyzed whether there is a relation between artistic and cultural activities of women and their party preferences. The variables such as reading books, newspapers and journals, frequency of internet usage, going to cinema, theater, opera and ballet and visiting museums were used. In democratic communities newspapers are one of the communal and political participation tools. The citizens get information about actuality from newspapers or other media tools (Dahl, 1963).

A big part of women in Turkey spend their spare time by watching TV. According to a generally accepted understanding, television decreases the interest towardsartistic activities. Due to the low education and income levels, the ratio of going to the cinema is very low among AKP women voters. Theater, opera and ballet activities are generally followed by over medium-aged audiences who may be defined as elite. We may say that older and high educated women with high income who voted for CHP participate in the art events. Younger women prefer art activities such as theater, cinema, music, and concerts (Geçer, 2013).

\section{Data Analysis Techniques}

Accurate prediction has become an important issue in all areas. Therefore, for a good prediction, a large number of studies have been tried to build 
appropriate models by using data mining techniques, multivariate statistical analysis, and other statistical or computational methods. In this study, machine learning techniques, namely decision trees and logistic regression, are employed as predictive tools. Machine Learning is the common name of the computer algorithms that model a problem according to the given observed data.

Decision trees are popular methods in data mining and successfully used to segment observations such as customers, genders, voters, characters, medical diagnoses, corporate bankruptcy, etc., into statistically significant groups that are used as a point of reference to make predictions. Their main purposes are segmentation, classification, and prediction based on adjusted significance testing (Kass, 1980; Quinlan, 1993; Breiman et al., 1984; Loh, 1997). A decision tree is a hierarchical data configuration in which each branch node represents a preference between alternatives and each leaf node represents a classification or decision. It breaks down a dataset into smaller and smaller subsets. The topmost decision node in the tree corresponds to the best predictor. Decision trees can be performed on dataset comprising both categorical and numerical data. They are usually implemented as a set of nested if-then-else statements. It gives a model that contains the rule set which is easy to explain and interpret helps in understanding the logical output of the classification results. There are many specific decision tree algorithms; CRT, C4.5, C5.0, CHAID, ID3, LAD tree, random forest and QUEST algorithms are some of them.

Regression analysis is a statistical tool for the investigation of relationships between an explained variable (Y; dependent variable, e.g party preference) and some predictor variables (X's; independent variables, e.g education, income, etc). The estimated regression function is $\mathrm{Y}=\mathrm{b}_{0}+\mathrm{b}_{1}$ $X_{1}+b_{2} X_{2}+\ldots .+b_{n} X_{n}$. The coefficients of the function show the relations between each of the independent variables and the dependent variable. For instance $b_{1}$ is the effect of one unit change of $\mathrm{X}_{1}$ on $\mathrm{Y}$ on average when all the other variables were kept constant. Unlike univariate analysis it considers other variables' effect on $\mathrm{Y}$ in the model by fixing them constant when the effect of an independent variable on the dependent variable is analyzed. Regression analysis, like parametric statistical methods, assumes that the residuals, or errors, must follow a normal distribution additionally to the assumption of homogeneous variance (homoscedastic) of residuals. 
When the dependent variable is binary or categorical logistic regression is preferred. Unlike the linear regression, logistic regression does not assume that the dependent variable or the error terms are normally distributed or has homogeneous variance. Also the relationship between independent variables and dependent variable need not be linear.

\section{Analyses}

The aim of the study was to determine the significant attributes of women in party selection. For this aim a total of twenty inputs (attributes, predictors) and one output (dependent variables) were implemented. The dependent variable as output is party preference, which has two outcomes: AKP (Justice and Development Party) or CHP (Republican People's Party). This output variable represents women votes in the elections in Turkey. The independent input variables are age, education, number of children, income level, family size, score on left-right scale, opinion on the gender equity, opinion on feminism, opinion on cohabitation, opinion on lifting headscarf ban, opinion on abortion, opinion on flirtation, wearing headscarf or not, Salah (prayer), fasting in Ramadan, reading the Koran, consumption of alcoholic beverages, residential area (urban-rural), culture score (culture scale is the average of its three components which are reading newspapers, reading journals, and reading books and has been measured by a 9 point scale; 1 never reads and 9; always reads), and sociability score (Sociability scale has 5 components, which are going to cinema, going to theatre, visits museums, going to opera and ballet, and going to live music concerts. 11 points scale was used to measure the sociability scale; 1: never goes, 11: always goes). Table 1 shows dependent and predictor variables and their scales.

The data for the study was collected in Dec 2013-Jan 2014. Nearly half of the Turkish voters are women and over $75 \%$ of Turkish population are AKP and CHP supporters. Therefore, we can assume our data is highly representative for Turkish women. It is important to know the ideological, religious, economical and cultural motives behind party selection of Turkish women for political parties, decision makers, sociologists and researchers. The cases (AKP or CHP) were unbalanced (AKP: 1392, 77,1\%, CHP: 414, $22,9 \%$ ) in our original sample data. It is advisable to correct imbalances in 
datasets to conform to specified test criteria (Wilson \& Sharda, 1994). Statistical or machine learning techniques have difficulties with unbalanced data since they incline to learn only the outcomes with high percentage groups and ignore outcomes with low percentage groups. Models have a higher chance for finding design that separate the groups if the data are well balanced with nearly equal numbers of outcomes. We balanced our cases as to be nearly $50 \%$ (AKP) and 50\% (CHP) by a random selection from our original sample data of AKP. For this aim, 420 cases were randomly selected from the AKP women voters. The analyses in this study are implemented by Waikato Environment for Knowledge Analysis.

Table 1.

List of Key Personal Attributes used in the Analysis

\begin{tabular}{|c|c|}
\hline Attribute & Description \\
\hline Age & Continuously variable \\
\hline Education level & $\begin{array}{l}\text { 1: no education 2: elementary, } 3 \text { : middle school, } 4 \text { : high } \\
\text { school, 5: undergraduate, } 6: \text { post graduate }\end{array}$ \\
\hline Number of Children & Continuous variable \\
\hline Income level & $\begin{array}{l}1: 0-500,2: 501-1000,3: 1001-2000 \\
2001-3000, \quad 5: 3001-5000, \quad 6:>5000\end{array}$ \\
\hline Family size & Continuously variable \\
\hline Left-right scale & $\begin{array}{l}\text { Continuously variable between } 1 \text { : very leftist, } \\
\text { very rightist }\end{array}$ \\
\hline Opinion on gender equality & 1: equal, 2: different, 3 : male superior, 4 : female superior \\
\hline Opinion on feminism & $\begin{array}{l}\text { 1: necessary and support feminism, } 2 \text { : necessary but don't } \\
\text { support, 3: unnecessary and don't support, } 4 \text { : } \\
\text { unnecessary and oppose, } 5 \text { : no idea }\end{array}$ \\
\hline Opinion on cohabitation & 1: very bad, 2: bad, 3: normal, 4: good, 5: very good \\
\hline Opinion on abortion & 1: positive, 2 : negative \\
\hline Opinion on lifting headscarf ban & 1: positive, 2 : negative \\
\hline Opinion on flirtation & 1: positive, 2 : negative \\
\hline Wear headscarf? & 1: yes, $2:$ no \\
\hline Pray? & 1: yes, 2: no, 3: sometimes \\
\hline Fast in Ramadan? & 1: yes, 2: no, 3: sometimes \\
\hline Read Koran? & 1:yes, 2 : no \\
\hline
\end{tabular}


Consume alcohol?

Residential place
1: no, 2: sometimes, 3 : yes

1: urban, 2: rural

Cultural scale (mean of reading newspapers, reading journals, Continuous variable (between 1 to 9. 1:never, 9:always) and reading books)

Socialization scale (mean of going to cinema, going to theatre, visiting museums, going to opera and ballet, and going to live Continuously variable (between 1 to 11 . 1: never, 11:always) music concerts

Party preference AKP, CHP

(WEKA). WEKA is a popular data mining suite developed at the University of Waikato, New Zealand (Witten \& Frank, 2005).

The performance of models used in binary is often measured by using a confusion matrix (Table 2). A confusion matrix is a table contains information about the actual and predicted classifications. In this study, we used overall accuracy, area under ROC curve (AUC), recall, and F-measure as performance measures. It is important to use different performance criteria to evaluate the learning methods of machine learning models. The short descriptions of the measures are given below.

Table 2.

Confussion Matrix

\begin{tabular}{l|c|c|} 
& Predicted YES & Predicted NO \\
\hline Actual YES & True Positive (TP) & False Negative (FP) \\
Actual NO & False Positive (FP) & True Negative (TN)
\end{tabular}

Overall Accuracy (AC): Correctly classified rate, which is one of the widely used performance criteria, shows the prediction success. For correctly calculation classified rate, the following formula is used: 


$$
\text { Accuracy }=\frac{T P+T N}{T P+T N+F P+F N}
$$

Precision: Precision is defined as the ratio of the number of True Positive (correctly predicted cases) to the sum of the True Positive and the False Positive (FP). It is calculated with the formula:

$$
\text { Precison }=\frac{T P}{T P+F P}
$$

Recall: Recall states the measure of how many of the true roles were extracted by the model (Rosario \& Hearst, 2004). It is defined as the ratio of the True Positive to the sum of the True Positive and the False Negative.

$$
\text { Recall }=\frac{T P}{T P+F N}
$$

Sensitivity: Sensitivity is also known as the Recall or True Positive rate. Specificity: This is also known as the True Negative Rate (TN). It is defined as the ratio of the number of the True Negative to the sum of the True Negative and the False Positive.

$$
\text { Specificity }=\frac{T N}{T N+F P}
$$

F-measure: F-measure is defined as the harmonic mean of precision and recall performance metrics (Goutte \&Gaussier, 2005).

$$
\mathrm{F}-\text { measure }=2 \mathrm{x} \frac{\text { precision } \mathrm{x} \text { recall }}{\text { precision }+ \text { recall }}
$$

ROC Area: The area under the ROC curve is one of the commonly used performance metrics to indicate the overall discrimination. A ROC area 
varies between 0.5 (no discrimination) and 1.0 (perfect discrimination) (Janssen et al., 2010).

\section{Results}

Logistic regression and decision tree machine learning techniques are applied for the data analysis. Many algorithms in decision tree have been proposed for classification in WEKA, such as J48-algorithm, LAD tree algorithm, Random forest algorithm, AD tree, Random tree, etc. We applied all the possible algorithms provided in WEKA to find the best classification of party preference. Among all classifiers, our experimental results show that the LAD (Logical Analysis of Data) tree give the highest sensitivity, specificity, accuracy and the minimum error. Next tables display the results of this analysis. Although TP (true positive) rate, recall, and ROC measurements of logistic regression are better than those measurements of LAD tree, all the other results, like number of correctly classified individuals, mean absolute error, precision, and F-measure of LAD tree are better than logistic regression results (Table 3, Table 4, and Table 5). Using the variables, logistic regression correctly classifies $84,5 \%$ of all the analyzed women voters. LAD algorithm in decision tree classifies $85,6 \%$ correctly. $84,8 \%$ of AKP and $86,5 \%$ of CHP women voters can be correctly classified by decision tree (table 5). LAD is one of the data mining methods for generating a multi-class alternating decision tree using the Logit Boost strategy which was first introduced in the '80s (Hammer, 1986). LAD suggests a way of analyzing data through combinatorial logic, Boolean functions, and optimization techniques. It differs from other conventional data mining methods by its ability to detect logical combinatory information about the observations. The LAD method detects patterns for which all the satisfying observations have a decidedly higher or lower show rate than the studied population. 
Table 3.

Classification Accuracy of the Training Dataset

\begin{tabular}{lll} 
& Decision tree & $\begin{array}{l}\text { Logistic } \\
\text { regression }\end{array}$ \\
\hline Correctly Classified Instances & $714(85,61 \%)$ & $705(84,53 \%)$ \\
Incorrectly Classified Instances & $120(14,39 \%$ & $129(15,46 \%)$ \\
Mean absolute error & 0,21 & 0,1982 \\
Root mean squared error & 0,34 & 0,3309 \\
Relative absolute error & $42,43 \%$ & 39,63 \\
Root relative squared error & $67,36 \%$ & 66,17 \\
Total Number of Instances & 834 & 834 \\
\hline
\end{tabular}

To measure the importance of predictor variables is important to identify and focus on the more important variables and to ignore or drop the least important ones. The decision tree model used in this study produced an appropriate measure of importance and was displayed in table 4 .

Table 4.

Prediction results for Party preference

\begin{tabular}{lllllllll}
\hline & $\begin{array}{l}\text { Accuracy } \\
(\mathrm{AC})\end{array}$ & TP Rate & FP Rate & Precision & Recall & Measure & Area & Class \\
\hline $\begin{array}{l}\text { Decision } \\
\text { tree }\end{array}$ & & 0,848 & 0,135 & 0,864 & 0,848 & 0,856 & 0,919 & AKP \\
& & 0,865 & 0,152 & 0,848 & 0,865 & 0,856 & 0,919 & CHP \\
$\begin{array}{l}\text { Weighted } \\
\text { avg, }\end{array}$ & 0,856 & 0,856 & 0,144 & 0,856 & 0,856 & 0,856 & 0,919 & \\
\hline $\begin{array}{l}\text { Logistic } \\
\text { regression }\end{array}$ & & 0,867 & 0,176 & 0,833 & 0,867 & 0,849 & 0,927 & AKP \\
$\begin{array}{l}\text { Weighted } \\
\text { avg, }\end{array}$ & 0,845 & 0,845 & 0,155 & 0,46 & 0,845 & 0,845 & 0,927 & \\
\hline
\end{tabular}


WEKA-produce rankings of attributes that are the importance of each variable based on the information gain score in the model. A variable is considered more important than another if its ranking is higher. Higher information gain means better discriminative power for classification.

Table 5 .

Confusion matrix in predicting AKP and CHP

\section{Predicted}

\begin{tabular}{lllll} 
Decision tree & & AKP & CHP & $\begin{array}{l}\text { Percent Correct } \\
84,8 \%\end{array}$ \\
\multirow{2}{*}{ Actual } & AKP & 356 & 64 & $86,5 \%$ \\
& CHP & 56 & 358 & \\
Overall Percentage & Total & 412 & 422 & \\
& & $49,4 \%$ & $50,6 \%$ & $85,6 \%$ \\
\hline \multirow{2}{*}{ Logistic regression } & & Predicted & \\
& AKP & AKP & CHP & Percent Correct \\
Actual & & 564 & 56 & $86,7 \%$ \\
& CHP & 73 & 341 & $82,4 \%$ \\
Overall Percentage & & 437 & 397 & \\
\hline
\end{tabular}

Table 6.

Representation of the relative importance of attributes for party prediction

\begin{tabular}{|c|c|c|c|c|c|c|c|c|c|}
\hline $\begin{array}{l}\text { Info } \\
\text { gain } \\
\text { score }\end{array}$ & Attribute & $\begin{array}{l}\text { Mean/ } \\
\text { Freq }\end{array}$ & $\mathrm{AK}$ & $\mathrm{CH}$ & $\begin{array}{l}\text { Info } \\
\text { gain } \\
\text { score }\end{array}$ & Attribute & $\begin{array}{l}\text { Mean/ } \\
\text { Freq }\end{array}$ & AKP & $\mathrm{CH}$ \\
\hline 0,364 & $\begin{array}{l}\text { Left-right } \\
\text { scale }\end{array}$ & Mean & 7,88 & 4,19 & 0,063 & $\begin{array}{l}\text { Family } \\
\text { size }\end{array}$ & Mean & 4,24 & 3,37 \\
\hline \multirow[t]{2}{*}{0,27} & \multirow{2}{*}{$\begin{array}{l}\text { Wear } \\
\text { headscarf }\end{array}$} & Yes & 343 & 93 & \multirow[t]{2}{*}{0,06} & \multirow{2}{*}{$\begin{array}{l}\text { Read } \\
\text { Koran }\end{array}$} & Yes & 344 & 230 \\
\hline & & No & 77 & 321 & & & No & 76 & 184 \\
\hline \multirow[t]{3}{*}{0,148} & \multirow{3}{*}{ Pray } & Yes & 266 & 93 & 0,058 & \multirow{3}{*}{$\begin{array}{l}\text { Culture } \\
\text { scale }\end{array}$} & \multirow[t]{3}{*}{ Mean } & \multirow[t]{3}{*}{4,58} & \multirow[t]{3}{*}{4,40} \\
\hline & & No & 110 & 153 & & & & & \\
\hline & & Sometimes & 44 & 168 & & & & & \\
\hline 0,145 & Consume & Yes & 1 & 13 & 0,057 & Income & $0-500 \mathrm{Tl}$ & 34 & 19 \\
\hline
\end{tabular}


International and Multidisciplinary Journal of Social Sciences, 9(3) 279

\begin{tabular}{|c|c|c|c|c|c|c|c|c|c|}
\hline & Alcohol & No & 413 & 279 & & level & $501-1000$ & 145 & 105 \\
\hline & & Sometimes & 6 & 122 & & & $1001-2000$ & 191 & 146 \\
\hline 0,132 & Fast in & Yes & 385 & 231 & & & $2001-3000$ & 37 & 93 \\
\hline & Ramadan & No & 11 & 87 & & & $3001-5000$ & 11 & 38 \\
\hline & & Sometimes & 24 & 96 & & & $5001 \mathrm{TL}$ or & 2 & 13 \\
\hline 0,12 & $\begin{array}{l}\text { Lift } \\
\text { headscarf }\end{array}$ & Positive & 396 & 257 & 0,045 & Feminis & $\begin{array}{l}\text { necessary and } \\
\text { support }\end{array}$ & 35 & 88 \\
\hline & Ban & Negative & 24 & 157 & & & $\begin{array}{l}\text { necessary but } \\
\text { doesn't support }\end{array}$ & 28 & \\
\hline 0,117 & & & & & & & $\begin{array}{l}\text { unnecessary and } \\
\text { doesn't support, }\end{array}$ & 88 & 84 \\
\hline & Abortion & Negative & 379 & 230 & & & $\begin{array}{l}\text { unnecessary and } \\
\text { oppose }\end{array}$ & 41 & 41 \\
\hline & & & & & & & no idea & 228 & 145 \\
\hline 0,106 & $\begin{array}{l}\text { Sociability } \\
\text { scale }\end{array}$ & Mean & 6,70 & 8,00 & 0,035 & $\begin{array}{l}\text { Number } \\
\text { of } \\
\text { children }\end{array}$ & Mean & 2,50 & 1,90 \\
\hline 0,099 & Cohabitati & Very bad & 345 & 237 & 0,028 & Age & Mean & 38,6 & 42,1 \\
\hline & on & $\mathrm{Bad}$ & 53 & 41 & & Nge & & & \\
\hline & & Good & 4 & 31 & 0,011 & Gender & Equal & 213 & 227 \\
\hline & & Very good & 2 & 6 & & equality & Different & 95 & 93 \\
\hline 0,097 & Flirtation & Positive & 228 & 360 & & opinion & Male superior & 93 & 59 \\
\hline & & Negative & 192 & 54 & & & Female superior & 19 & 35 \\
\hline 0,067 & & No Education & 48 & 13 & 0,001 & & Urban & 382 & 383 \\
\hline & Education & Elementary & 215 & 155 & & Resident & Rural & 38 & 31 \\
\hline & & Middle school & 66 & 55 & & area & & & \\
\hline & & High school & 75 & 133 & & & & & \\
\hline & & Undergraduat & 16 & 50 & & & & & \\
\hline & & Post graduate & 0 & 8 & & & & & \\
\hline
\end{tabular}

Table 7.

Summary of Classification Rule Set

Rule Classification Rule Set

Classifi

cation

$1 \quad$ IF (Headscarf=yes)

AKP

2 IF (Headscarf $=$ No) AND IF (Alcohol=no)

AKP

3 IF (Headscarf=No) AND IF (Alcohol=Yes or Sometimes)

CHP

4 IF (Left-right scale $>=6,5$ )

AKP

5 IF (Left-right scale $<6,5)$ AND IF (Flirt=Positive) 


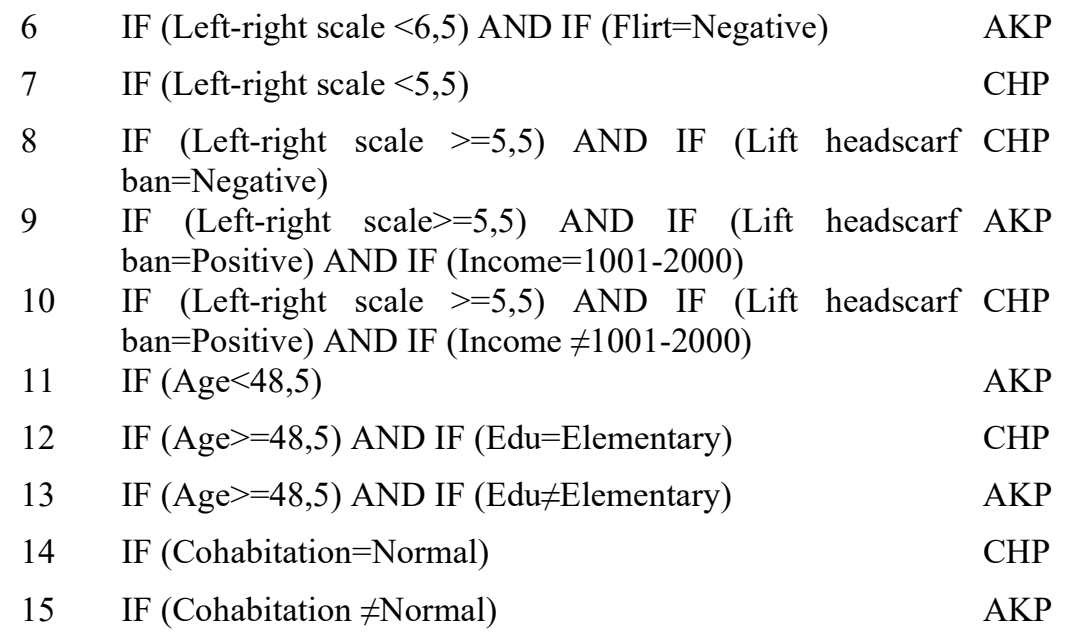

To discover the impact of personal attributes on a party selection, the degree of variable importance for the decision tree model was evaluated and presented in Table 6 . This provided valuable information for identifying the most important attributes upon which to focus in order to predict a woman's party preference. The WEKA gives information gain scores of attributes which is used to rank attributes. It is a ranked list of the most predictive features according to its Information Gain score. This is an Information Theory metric that takes into consideration how the entropy (or separation) of the space points (individuals) changes when using one attribute. A high score in Information Gain means it is easier to classify the individuals. According to Table 6, the Left-Right scale was the leading attribute in the model, while wearing a headscarf was the next most important attribute in the decision tree model. Prayer was the third most important attribute and consumption of alcoholic beverages was the fourth. Then, fasting in Ramadan, opinion on lifting headscarf ban, opinion on abortion, and sociability score follow them. These variables have the highest impact on predicting party preference of Turkish women. Residential region (rural or urban), opinion on gender equality, age, number of children, and opinion on feminism were the least important predictors. 
The rules set that extracted from the classification tree are presented in Table 7 to highlight the criterion used for formulating classification rule set by the WEKA classifier. A thorough review of the classification rule set also gives the impression that it is, in fact, a set of nested if statements that can readily be expressed and are straightforwardly understandable. The findings obtained from our experimentation appear to be quite interesting. Some examples for estimation of a woman from table 7 are;

IF (Headscarf=yes) then the estimated result that the woman vote for is AKP IF (Headscarf=No) AND IF (Alcohol=Yes or Sometimes) then estimated result that the woman vote for is $\mathrm{CHP}$

IF (Left-right scale $<6,5$ ) AND IF (Flirt=Positive) then the estimated result that the woman vote for is CHP

IF (Left-right scale $>=5,5$ ) AND IF (Lift headscarf ban=Positive) AND IF (Income $=1001-2000)$ then estimated result that the woman vote for is AKP

\section{Conclusion}

In this study, we analyzed the religious, ideological, cultural, social, economic, and demographic differences of women supporters of AKP and CHP. In other words, the important attributes of women in party selection decisions were analyzed and ranked so that according to these attributes, a woman's party decision can be estimated. The results can be used by a political party to create policy and decide where to stand in some conflicting issues since the party supporters' beliefs and thoughts are known. The attributes used in the study are age, opinion on flirtation, opinion on cohabitation, education level, number of children, income level, number of people in the house, opinion on gender equality, opinion on feminism, rightleft scale, opinion on lifted headscarf ban, opinion on abortion, wearing headscarf, prayer, fasting in Ramadan, reading Koran, alcoholic beverages consumption, residential area (urban-rural), cultural activities, and social activities. Participation of women in events such as cinema, theater, opera, ballet, or live music activities are collected under the title of social activities; and reading newspapers, reading journals, and reading books are collected under cultural activities. 
We can say that AKP and CHP voters have significant differences according to the attributes analyzed in the study.

AKP women voters are more rightist but CHP women voters are more leftist (the mean of left-right scale were 7,88 and 4,19 respectively). AKP women voters are more likely to wear headscarf, perform salah, fast in Ramadan, read Koran (table 6). AKP women voters support the lifting of the headscarf ban in a greater extent than the CHP voters. AKP women voters oppose to flirtation and abortion more than CHP women voters. As seen from table 6, a big part of women who voted for AKP, stated that they are opposed to abortion. Among women who vote for CHP, the number of women who are opposed to abortion is much more than the ones who support it. Along with that, it is seen that religious women sometimes have abortion. CHP women voters are more social, have fewer children, are more educated and have higher income than AKP women voters. The biggest part of women who voted for AKP was graduated from primary school (table 6). The reason of this is that women who come from religious and conservatist families were deprived from the education right in the previous years due to head-scarf ban. Almost all of women who vote for AKP stated that they do not consume alcohol. While more than half of the women who voted for CHP do not consume alcohol, the number of women stating that they sometimes use alcohol is high. There is no difference between the two groups on the ratio of people that believe in the equality of male and female. But the ratio of AKP voters believing that males are superior to females is more than the ratio in CHP voters. Moreover, the ratio that believes females are superior to males is higher in CHP than in AKP. No significant difference found between the two groups by their living area either rural or urban.

When all the above attributes are analyzed by logistic regression and decision trees, decision trees gave better results than logistic regression in this study. Among the decision tree algorithms, LAD tree gave the best fitting results. According to the results of this algorithm 85,6\% of Turkish women can accurately be predicted whether they vote for AKP or CHP. The most predictive attributes that reflect the highest differences between AKP and CHP women voters are left-right scale, wearing headscarf, prayer, alcohol consumption, fast in Ramadan, opinion on lifting headscarf ban, opinion on abortion and sociability score (going to cinema, going to theatre, 
visiting museums, going to opera and ballet and going to live music concerts (AKP voters are less social than the CHP voters). The least important features that discriminate between the two groups are residential area, opinion on gender equality, age, number of children, and opinion on feminism. Other variables which are opinion on cohabitation, opinion on flirtation, education level, family size, reading the Koran, cultural scale, and income level have moderate importance as predictive tools.

According to the analyses, religiousness is the most important ones that are effective on voting preferences of women in Turkey. When religious values, attitudes, and behaviors are taken into consideration together, women with headscarf who have religious values and attitudes prefer AKP. Women who vote for CHP are women who are inclined to left section and whose education levels are high. The results imply that, CHP is not able to reach the base. The main reasons of this is that CHP is not able to renew itself with the discourse resulted from being founder party, it is not able to produce discourses that will appeal to the base, it gives a military and bureaucratic party image and it has an image far to the masses. when CHP develops discourses towards women who wear headscarf and who are religious leads to the risk of losing its current base. In fact, this situation creates a paradox for CHP. When it insists on continuance of the reforms, it will stay as a minority party. In case it makes changes on its discourses with the aim coming to power, it has been getting far away from its contemporarization target. If CHP does not develop policies that will cover women without making any discrimination, we may say that it will not get votes from women with headscarfs. The aspects such as opinion on feminism, urbanrural discrimination and women-men equality do not draw attention as important variables that affect behaviors of women voters

The economic performance of governments has an impact on voter preference. This impact emerges especially during economic crisis. In Turkey, the parliamentary elections held on November 3, 2002 is an example for this fact. The parties that formed the coalition in the government were not able to get the enough vote even to enter to the parliament in that election (Çinko, 2006). The vote of the biggest partner of the coalition decreased from $22.2 \%$ to $1.2 \%$. Although the country's economic condition is important in voting behavior and especially due to economic crisis people may change their parties, they don't vote for a party that is opposite of their 
ideology and beliefs. The party people vote for is again ideologically close to their ideology. The evidence of this statement can be found in the distribution of the rightist and leftist parties in the parliament after the transition to the multi-party system in Turkey. It is seen that the right parties vote ratios which were highly stable, were between $55 \%$ and $65 \%$, in the 17 parliamentary elections from 1950 to 2015 . This fact shows that the analyzed ideological and religious variables in this study are not conjunctural.

\section{References}

Adakl1, G. (2009). 2002-2008: Türk medyasında AKP etkisi. In İ. Uzgel \& B. Duru (Eds.). AKP Kitabı: Bir dönemin bilançosu (pp. 559-613). Phoenix.

AK Parti. (2015). Parti Programı AK Parti website:https://www.akparti.org.tr/site/akparti/parti-programi\#bolum

Aksoy, H. A. (2015). Invigorating Democracy in Turkey: The Agency of

Organized Islamist Women. Politics \& Gender, 11(01), 146-170. https://doi.org/10.1017/S1743923X1500001X

Arat, Y. (2010). Religion, Politics and Gender Equality in Turkey: Implications of a Democratic Paradox? Third World Quarterly, 31(6), 869-884. https://doi.org/10.1080/01436597.2010.502712

Berger, P. L. (1999). The desecularization of the world. A global overview.

In P. L. Berger (Ed.), The Desecularization of the World: Resurgent Religion and World Politics. Ethics and Public Polity Center.

Breiman, L., Friedman, J. H., Olshen, R. A., \& Stone, C. J. (1984). Classification and Regression Trees. Chapman \& Hall/CRC.

Cindoglu, D., \& Zencirci, G. (2008). The Headscarf in Turkey in the Public and State Spheres. Middle Eastern Studies, 44(5), 791-806. https://doi.org/10.1080/00263200802285187

Çağatay, N., \& Soysal, N. Y. (1990). Uluslaşma Süreci ve Feminizm Üzerine Karşılaştırmalı Düşünceler. Kadın Bakış Açısından 1980’ler Türkiye 'sinde Kadın. İletişimYayınları.

Çaha, Ö. (2010). Sivil Kadın. Türkiye'de Sivil Toplum ve Kadın, Savaş Yayınları.

Çarkoğlu, A., \& Toprak, B. (2000). Türkiye'de Din, Toplum ve Siyaset. Türkiye Ekonomik ve Sosyal Etüdler Vakfı. 
Çınar, M. (2008). The Justice and Development Party and the Kemalist Establishment. In Ü.Cizre (ed.), Secular and Islamic Politics in Turkey: The Making of the Justice and Development Party(pp. 109-131). Routledge.

Çinko, L. (2006). Seçmen Davranışları İle Ekonomik Performans Arasındaki İlişkilerin Teorik Temelleri ve Türkiye Üzerine Genel bir Değerlendirme, Ankara Üniversitesi SBF Dergisi, 61-1.

Dahl, R. A. (1963). Modern Political Analysis. Prentice-Hall Inc.

Dalmış, I., \& Aydın, E. (2008). The Social Bases of the Justice and Development Party. In Ü.Cizre (ed.), Secular and Islamic Politics in Turkey: The Making of the Justice and Development Party (pp. 201-222). Routledge.

Ergüder, Ü. (1980). Changing Patterns of Electoral Behaviour in Turkey. Boğaziçi Üniversitesi Dergisi, VIII-LX, 45-81.

Erkan, H. (2000). Bilgi Uygarlı̆̆ için Yeniden Yapılanma, İmge Kitabevi Yayınları, Ankara

Esmer, Y. (1995). Parties and the Electorate: A Comparative Analysis of Voter Profiles of Turkish Political Parties. In Ç.Balim et. al. (eds.), Turkey: Political, Social and Economic Challenges in the 1990s. (pp. 7489). E.

Frey, F. W. (1975). Patterns of elite politics in Turkey. Political elites in the Middle East, 41-82.

Geçer, E. (2013).Medya ve Popüler Kültür: Diziler, Televizyon ve Toplum.OkurKitaplığı.

Goutte, C., \& Gaussier, E. (2005, March). A probabilistic interpretation of precision, recall and F-score, with implication for evaluation. In European Conference on Information Retrieval (pp. 345-359). Springer, Berlin, Heidelberg. https://doi.org/10.1007/978-3-540-31865-1_25

Göle, N. (1997). Secularism and Islamism in Turkey: The Making of Elites and Counter-Elites. The Middle East Journal, 1, 46-58.

Gönenç, L. (2006). 2000'li Yıllarda Merkez-Çevere Ilişkilerini Yeniden Düşünmek. Toplum ve Bilim, 105, 129-52.

Guveli, A. (2011). Social and economic impact of the headscarf ban on women in Turkey. European Societies, 13(2), 171189.https://doi.org/10.1080/14616696.2010.547942 
Hammer, P. L. (1986).Partially defined Boolean functions and cause-effect relationships.International Conference on Multi-Attribute Decision Making Via OR-Based Expert Systems, University of Passau. https://doi.org/10.1007/BF02614316

Hammond, P. (1999). Can Religion be Religious in Public? The Power of ReligousPublicus.In W. H. Swatos\&J. K. Wellman (eds.), The Power of Religious Publics: Staking Claimsin American Society(pp.19-31).Praeger Publishers.

Heper, M. (1985). The State Tradition in Turkey. Eothen Press.

Hürriyet. (2012). Diyanet İşleri Başkanı Görmez'den 'Kürtaj' Açıklaması, http://www.hurriyet.com.tr/gundem/20687889.asp

Ilyasoğlu, A. (1994). Örtülü kimlik: İslamcı kadın kimliğinin oluşum öğeleri (Vol. 5). Metis Yayınları.

Janssen, K. J., Donders, A. R. T., Harrell Jr, F. E., Vergouwe, Y., Chen, Q., Grobbee, D. E., \&Moons, K. G. (2010). Missing covariate data in medical research: to impute is better than to ignore. Journal of Clinical Epidemiology, 63(7),

721-727.

https://doi.org/10.1016/j.jclinepi.2009.12.008

Kalayc1, M. (2017). 16th April Referendum in the Context of Consolidating the Rightist Voters' Block in Turkey. Strategic Public Management Journal, 3, 151-160.

Kalaycioğlu, E. (1994). Elections and Party Preferences in Turkey Changes and Continuities in the 1990s. Comparative Political Studies, 27(3). 402424.https://doi.org/10.1177/0010414094027003004

Kass, G. (1980). An exploratory technique for investigating large quantities of categorical data. Applied Statistics, 29(2), 119-127. https://doi.org/10.2307/2986296

Khan, M. N. A., Qureshi, S. A., \& Riaz, N. (2013). Gender classification with decision trees. International Journal of Signal Processing, Image Processing and Pattern Recognition, 6, 165-176.

Keyman, E. F., \& Öniş, Z. (2003). Turkey at the Polls: A New Path Emerges. Journal of Democracy, 14(2), 95-107.

Lewis, B. (2008). Modern Türkiye'nindoğuşu. (Çev. B. B. Turna). ArkadaşYayıncılık

Loh, W. Y., \& Shih. Y. S. (1997). Split selection methods for classification trees. StatisticaSinica, 7, 815-840. 
Mardin, Ş. (1973). Center-periphery relations: A key to Turkish politics? Daedalus, 169-190.

Mardin, Ş. (1995). Türk Siyasasını Açıklayabilecek Bir Anahtar Merkez Çevre İlişkileri. In M. Türköne, \& T. Önder (eds.), Türkiye'deToplum ve Siyaset Makaleler(pp. 34-76). İletişim

Mert, N. (2007). Merkez sağın kısa tarihi (Vol. 87). Selis Kitaplar.

Milliyet (2009). Alkol tüketi miartıyor. Milliyet website:

https://www.milliyet.com.tr/ekonomi/alkol-tuketimi-artiyor-1139156

Narli, N. (1999). The rise of the Islamist movement in Turkey. Middle East Review of International Affairs, 3(3), 39.

Ozbudun, E. (1976). Social change and political participation in Turkey. Princeton University Press.

Ozbudun, E., \&Tachau, F. (1975). Social Change and Electoral Behavior in Turkey: Toward A 'Critical Realignment'? International Journal of Middle East Studies, 6(4), 460-480.

Pak, S. Y. (2006). Politicizing imagery and representation of Muslim womanhood: reflections on the Islamic headscarf controversy in Turkey. Asian Journal of Women's Studies, 12, 32-60, https://doi.org/10.1080/12259276.2006.11666016

Resmi Gazete. (2013). 6487 Sayılı Kanun. Bazı Kanunlar İle 375 Sayılı Kanun Hükmünde Kararnamede Değişiklik Yapılması Hakkında Kanun http://www.resmigazete.gov.tr/eskiler/2013/06/20130611-1.htm

Rosario, B., \& Hearst, M. A. (2004). Classifying semantic relations in bioscience texts. In Proceedings of the 42nd annual meeting on association for computational linguistics. Association for Computational Linguistics, 430.https://doi.org/10.3115/1218955.1219010

Ruspini, E., \&Dale, A. (eds) (2002).The Gender Dimension of Social Change: the Contribution of Dynamic Research to the Study of Women's Life Courses. The Policy Press.

Sabah Gazetesi (2014). Bakanlık Kürtaj Rakamlarını Açıkladı. http://www.sabah.com.tr/fotohaber/gundem/bakanlik-kurtaj-rakamlariniacikladi

Sakallioğlu, Ü. C. (1996). Parameters and strategies of Islam-state interaction in Republican Turkey. International Journal of Middle East Studies, 28(2), 231-251. http://www.jstor.org/stable/176426 
Shils, E. (1975). Center and Periphery: Essays in Macrosociology. The University of Chicago Press.

Tachau, F. (1991). The Republican People's Party, 1945-1980. Political Parties and Democracy in Turkey, 99-107.

Tamer, M. (2015). AKP \% 25 kadın vekil diyor, CHP? Milliyet website:http://www.milliyet.com.tr/akp-25-kadin-vekil-diyor-chp

Tekeli, Ş. (1993). 1980'ler Türkiye'sinde Kadın Bakış Açısından Kadınlar, İletişimYayınları, İstanbul, 15-50.

Toprak, B. (1995). Islam and the Secular State in Turkey. In C.Balım, E.Kalaycioglu, C.Karatas, G.W1throw,\& F. Yasamee (Eds.), Turkey: Political, Social And Economic Challenges in The 1990s(pp. 90-96). E. J. Brill.

Toprak,

B.

(2009).

Türkiye'deFarklıOlmak:

Din

veMuhafazakarlıkEksenindeÖtekileştirilenler. Metis Yayınları

Tuncel, G., \& Gündoğmuş, B. (2012). Türkiye Siyasetinde Merkez-Çevrenin

Dönüşümü Ve Geleneksel Merkezin Konumlanma Sorunu. İktisadi Ve İdari Bilimler Fakültesi Dergisi, 14(3), 1-22.

Quinlan, J. R. (1993). C4.5: programs for machine learning. Morgan Kaufmann Series in Machine Learning

Wikipedia (n.d.). Kemalism. Retrieved from Wikipedia website:https://en.wikipedia.org/wiki/Kemalism

Wilson, R. L., \& Sharda, R. (1994). Bankruptcy prediction using neural networks. Decision support systems, 11(5), 545-557. https://doi.org/10.1016/0167-9236(94)90024-8

Witten, I. H., \& Frank, E. (2005). Data Mining: Practical machine learning tools and techniques. Morgan Kaufmann Series in Data Management Systems

Havva Çaha is a professor at the Faculty of Economics and Administrative Sciences, Mardin Artuklu University, Mardin, Turkey.

Nizamettin Bayyurt is professor at the Faculty of Management, Istanbul Technical University, Istanbul, Turkey

Contact Address: bayyurt@itu.edu.tr 